\title{
Polysèmes
}

Revue d'études intertextuelles et intermédiales

\section{Traumatic Layerings of Self: Scrapbooking Personal Photographs in One Hundred Demons}

\author{
Nancy Pedri
}

\section{(2) OpenEdition}

\section{Journals}

\section{Electronic version}

URL: http://journals.openedition.org/polysemes/3460

DOI: $10.4000 /$ polysemes.3460

ISSN: 2496-4212

Publisher

SAIT

\section{Electronic reference}

Nancy Pedri, «Traumatic Layerings of Self: Scrapbooking Personal Photographs in One Hundred Demons », Polysèmes [Online], 19 | 2018, Online since 30 June 2018, connection on 01 May 2019. URL http://journals.openedition.org/polysemes/3460 ; DOI : 10.4000/polysemes.3460

This text was automatically generated on 1 May 2019.

Polysèmes 


\title{
Traumatic Layerings of Self: Scrapbooking Personal Photographs in One Hundred Demons
}

\author{
Nancy Pedri
}

\begin{abstract}
Photographs ... are clouds of fantasy and pellets of information.

(Susan Sontag, On Photography, 69) Historically, personal pictures are deeply unreliable, but it is in this very unreliability that their interest lies.

(Patricia Holland, “'Sweet it is to scan...': Personal Photographs and Popular Photography", 118)
\end{abstract}

\section{Personal photography and the self}

1 Very soon after photography was introduced in 1839, personal photographs secured a privileged place in both private and public narratives of self. Personal photographs and questions of identity have gone hand in hand throughout the history of photography, starting with the daguerreotype (1840s), then with carte-de-visites (1850s), then with snapshots made with a Kodak Brownie camera (1880s) or Instamatic (1960s), and right up to present-day trends where we literally carry around and share a collection of cellular phone selfies. With every subsequent technological invention geared towards making both the photographic camera and the photographic image more mobile, personal photographs increasingly prove to be a medium through which individuals confirm and explore, tell and package their identities and personal histories (Holland 2001, 119).

Personal photography has always been used to manufacture images of self, but personal photographs are far more than private images, as Pierre Bourdieu argued when describing photography as a middle-brow art (Bourdieu 31). Although they are records of one's identity, the acts of creation, collection, and viewing that give rise to and 
encompass personal photographs unfold within a network of social practices that shape both the photographic record and the identity it speaks to. Professional and amateur personal photographs give "the public image of a private person" (Clarke 103). Like family photographs, these photographs are created with the aid of what Marianne Hirsch describes as a "screen made up of dominant mythologies and conceptions" (M. Hirsch 7-8). As both markers and creators of identity, personal photographs also advertise a self, situating the private firmly in the public domain.

Photographic albums-material or digital albums-are perhaps at once the most private and public collections of personal photographs. In them, photographs are dated and stored; they are selected, privileged, and carefully organized; they are displayed, looked at, and shared. Each image in a photographic album places its subject within the fabric of its personal history, reminding us what we looked like, who we were, where we were, who we were with. For its creator, the photographs serve as solid points of reference of a life lived and a self contemplated; for its viewers, they are photographs that invite "curiosity about personalities and relationships" (J. Hirsch 6). Like letters or diaries, photographic albums are records of personal experience and private selves that are made, collected, and viewed. ${ }^{1}$ At the same time, they are collections of photographs that are familiar, even hackneyed. As carefully crafted compilations-"they will include significant moments and suitable family members and rigorously exclude others" (Holland 1991, 7)-personal photographic albums most often represent an acceptable version of self, a self that conforms to ideal images of both identity and its supporting institutions. Positioned firmly within public conventions of the image and of the social institutions that inform both identity and personal photography (family, religion, death, and so forth), photographic albums collect meanings of personal identity that are as social as they are personal.

4 Just as the albums that collect them, personal photographs are also highly problematic representations of self in that they raise questions as to precisely what, and who, is represented. In both taking and viewing them, fantasy and reality mix (Holland 2001, 116; Lee and Pultz 58); inner and outer self are confused (Clarke 102); aesthetic, cultural, ideological, sociological, and psychological interactions are played out (Bourdieu). In this predication of an ideal, desired, and oftentimes grossly conforming version of self, personal photographs also show what the self is not. The incongruity between what is shown and what is concealed, between the ideal image and the lived experience that is played out consciously or subconsciously when engaging with personal photographs posits acts of recognition alongside acts of misrecognition. It is within those acts of misrecognition that personal photographs "can be material for interpretation" (Kuhn 18); they can be sites that generate memories, personal histories, but also stories. The trace of personal identity that they hold thus proves to be merely a fixed point where multiple versions of self intersect, with some pictured, others alluded to, and others effaced altogether.

5 Hence, personal photographs may (re-)anchor the subject in the real world by accentuating physical embodiment, but they also betray a divided self. They offer up for contemplation a partial image of self that in its incompleteness inevitably suggests a multiplicity of self which evades representation, but which is known by the subject and readers alike. And, like family albums, personal photographs are entrenched behind a wall of silence. Staged, selected, and slotted within an acceptable story of self, an indeterminate number of secrets lie beneath their surface. Part of their lure rests in not 
showing traits, circumstances, and events that are not easily accommodated in ideal perceptions of self, such as disease, violence, or deviant behavior.

6 It is no wonder then that personal photographic images can pose major obstacles for writers of life-writing. In Mapping Our Selves, Helen Buss argues that oftentimes autobiographers have to contend with cultural myths that do not capture the particulars of their personal self (Buss 29). In her examination of the intersection of photographs and autobiographical practice, Linda Haverty Rugg has observed that photographs in autobiography "insist on something material, the embodied subject, the unification of author, name and body" and, at the same time, point to a plurality of selves (Rugg 13). Seriously complicating the referential status of both photography and autobiography, Rugg positions the question of representing self in the intersecting space of presence and absence, showing and concealing. It is this space, where a singular, static image of self contains layers and layers of self, which, if engaged with critically, can be most productive for exposing those layers of identity that are hidden by and across personal photographs and their history.

7 A number of subjects who have felt the limitations of existing representations or vocabularies of self, especially those who articulate a "forbidden narrative" of trauma (Pedri), have turned to personal photography to construct new frameworks and name alternative priorities. The ambiguity and dual pull towards evidential documentation (showing) and constructed ideal (obscuring) of personal photographs have made them particularly attractive to those who struggle to establish a sense of self in the wake of traumatic experiences. Janet Williamson, in her autobiography Crybaby! about childhood incest, includes personal photographs of herself aged three alongside reproductions of the deceptive captions scribbled across their reverse side to expose personal photographs as holding meaning in both what is shown and what is not shown. Her critically engaged inclusion of personal photographs in her autobiography exposes them not as truthfully recording, but as re-writing a past identity and life. Daphne Scholinski also adopts untraditional uses of personal photographs in her autobiography about the trauma she experienced when her sexuality was medicalized as a psychic disorder. The Last Time I Wore a Dress relates how her sense of self was shattered when she was diagnosed with gender identity disorder. In it, she includes seventeen personal photographic portraits that are characterized by the absence of a clearly defined body and blurry hands. These provocative photographs repeated with slight variation at the beginning of each chapter of the book signal, through a showing of absence, the traumatic split of a self cognisant of being seen, viewed, constructed, but remaining hidden, unknown, unrepresented in those very acts of identity-creation. As in Williamson's autobiography, Scholinski's unusual, highly critical use of personal photographs renders productive the tension between what John Tagg has called "the ecstasy of realism" and "the poverty of photography" (Tagg xxxvi).

8 Uses of personal photography that challenge and subvert collective understandings of personal photography and its relation to identity have become over the last decade a popular means for autobiographers to address and trouble the relationship between outer and inner expressions of self, a split that is "felt most strongly by people affected by trauma" (El Rafaie 63). Several graphic memoirs have also incorporated personal photographs into their narratives of trauma. Cancer Vixen (Marchetto), Depresso (Brick), Mom's Cancer (Feis), Psychiatric Tales (Cunningham), and other examples of graphic pathography rely on personal photographs to tell their stories, as do A Chinese Life (Ôtié), 
Alan's War (Guibert), and Maus (Spiegelman), three graphic memoirs that deal with war or other politically traumatic experiences. The subjects of these graphic memoirs feel the weight of articulating a self after a traumatic experience or series of experiences that significantly shaped the understanding of it. They are subjects that experience a split in self, an instability or disintegration of self as a result of trauma. By including personal photographs in their narratives, they become careful readers of their own photographs and are thus able to "test their own identities against those on offer" (Lee and Pultz 59). Ultimately, they turn to personal photographs as part of the process to represent histories of self that run counter to the dominant views of what can be shown and, by extension, known.

9 Graphic memoir's extreme formal flexibility and heavy reliance on visual storytelling practices have given rise to an increased use of "exploratory styles" (Holland 1991, 9) or "experimental" techniques (Kacandes) that combine artistic expressive forms to render as accurately as possible the layers of a split identity. The need to find innovative ways to represent the self is thus in line with the genre's accentuated focus on unofficial histories and especially histories of trauma (Gilmore 128). In graphic memoir, personal photographs are often marked up, symbolically embellished, cropped and framed, captioned, or otherwise altered. They are, in other words, scrapbooked.

Scrapbooking personal photographs provides graphic memoirists with the possibility to sort and choose photographs to memorialize (Tamas 87). They also provide occasion to layer interpretations and contexts onto personal photographs that do not or, better, cannot capture the importance or gravitas of what is not shown. Scrapbooked photographs often consist of layered additions to personal photographs, whereby the original photographic artefacts are altered and reformulated "by glazing, embossing, sewing, punching, tearing, cutting, and/or distressing them" (Tamas 87-88). The end product carries both hidden and not-so-hidden meanings, effacements of and additions to the original photograph. This layered texture of scrapbooked photographs addresses the fragmented collection of experiences and emotions that comprise a split self, a self that struggles to understand itself within a web of recorded experiences and unrecorded personal feelings towards those experiences.

11 Scrapbooking is a critical engagement with traditional forms of representation, forms such as the personal photograph that are regulated by habit and socio-cultural norms. Valued for its presentation of raw material and sources of knowledge, scrapbooking-and artistic practices associated with scrapbooking-accommodates trauma in a unique way that personal photographs or graphic memoir alone cannot. ${ }^{2}$ Judith Lewis Herman has emphasized that the "work of reconstruction [through narrative] actually transforms the traumatic memory, so that it can be integrated into the survivor's life story" (Herman 175). Trauma, however, actually causes a break in a self narrative, a narrative that is instrumental in forming a sense of a coherent self identity (see Eakin 101). It follows that the turning of traumatic events into a narrative that can be shared often entails confused, unstructured stories, stories that are "full of gaps, condensations and substitutions" (Stacey 98). Scrapbooking is an art of gaps, condensations, and substitutions. The story it gives rise to is one which lacks in coherence, which is provisional and incomplete, and which frustrates attempts of knowing for certain. Its formal properties and narrative outcomes makes scrapbooking particularly attractive to memoirists who set out to represent an identity that has been impacted by traumatic 
events and is thus positioned outside ideal constructions and standard representations of self.

\section{Scrapbooking personal photographs}

One Hundred Demons by Lynda Barry relies on several thematic and stylistic features that effectively speak to the split self of trauma. The graphic memoir tells of a traumatic childhood where she suffered under what she describes as a monstrous, "unpredictable and quite violent" (Barry 91) mother, a mother who repeatedly emphasized the ugliness and stupidity of her daughter. She tells of feeling suffocated under her mother's critical eye and of how her psychological and emotional growth was stunted by "bad love" (Barry 24). Barry portrays her rebellious teens, where drugs and sex provided a much needed escape from the pain of what Sophie Tamas, following Judith Herman, calls "everyday trauma" to describe "forms of trespass in which intimate relational spaces marked by expectations of safety are breached by violence and betrayal of trust" (Tamas 90). Art provided a much welcomed avenue of relief for Barry, who in One Hundred Demons reflects on how writing and drawing comics provided an outlet which allowed her to confront and begin to process the impact on self of everyday trauma.

Barry has a striking commitment to narrate what Aline Kominsky-Crumb, a graphic memoirist who also relies on scrapbooking in her Need More Love (2007) to tell of her everyday trauma, describes as "crazy primitive stuff" (1990, n.p.). Thematically, this commitment translates into a crude, raw form of honesty where otherwise private, secret experiences are shared openly. Although critiqued as presenting ugly, misshapen, even monstrous representations of self and of others, Barry is committed to constructing a subject that reflects her "real" bodily, mental, and emotional life as she feels it to be. Formally, the commitment to "crazy primitive stuff" entails an art practice that flouts comics conventions, eschewing traditional, "normal comics form" (KominskyCrumb 1990, n.p.). Although a normal comics form is difficult to define, especially given the extreme flexibility of the form, some standard visual practices constitute a grammar or language of comics. These include the narrating of a story with drawn images, but also other static images (maps, charts, photographs, etc.); a sequential ordering of images, usually separated by gutters or other gaps; and an aesthetically coherent or integrated style throughout the book. Breaking away from these and other traditional formal features of comics clears the way for Barry to tackle head on the honest telling of her everyday trauma, while also capturing its disorderly, inconclusive quality.

The everyday is of primary importance in graphic memoir, a comics genre that focuses on the personal experiences of a particular subject and how those experiences were livedconcretely and emotionally-by that subject. The graphic memoir proves a critical interface between experience and the interpretation of self. Personal photographs, too, record dailiness, but (as shown above) theirs is a dailiness most often inscribed within socio-historical conventions, regulatory narratives, and expectations of what a life and the subject living that life should look like. Scrapbooked personal photographs, by contrast, cut through the personal photograph's compliant fabrication of life to share with graphic memoir an accented concern with representing the subject's experience of a life lived, the way of being and feeling oneself. Whether narrated, packaged, or adjusted, private, everyday experience runs through all three methods of life-writing. 

techniques) into its telling. Perhaps more than any other narrative strategy used, the altering of personal photographs through scrapbooking techniques highlights the struggles a subject who experienced everyday trauma undergoes to work through and against existing knowledges of self, and to begin to reach a more integral understanding of self. Throughout One Hundred Demons, Barry overlays personal photographs with paper, ink, stamps, ribbons, sparkles, decorative ephemera, and other everyday materials; alters them by painting, cutting, tearing, glazing, colouring, or otherwise distressing them; and assembles the scrapbooked personal photographs in elaborate compositions that include other materials so that her graphic memoir resembles a scrapbook, "material manifestations of memory" (Tucker 3 ) that "implore us to remember who we were, and why it mattered" (Helfand 171). ${ }^{3}$ Like scrapbooks, One Hundred Demons is a multimodal form of life-writing born from remembering. In it, Barry collects everyday, familiar materials and weaves them into a fragmented, incomplete, and unsettling honest personal narrative of a past life and its impact on the past and present self. multi-coloured water-painted backgrounds, scrapbook designs and techniques feature heavily in Barry's One Hundred Demons, a collection of seventeen tightly interconnected short "autobifictionalography" stories (Barry, n.p.). Each story is introduced with a twopage collage title page comprised of verbal text and visual images, decorative borders, origami animals, glued on flowers, doilies, cut-out pictures (from magazines, colouring books, and previous sketches), newspaper scripts, material trim, and other seemingly random, everyday materials. These colourful, complex pages set the stage for the story that follows (Fig. 1). Although in them words, images, fabrics, and other materials are pieced together in a seemingly incongruous, unintelligible way, the suggestive pairings, such as a framed picture portraying a head louse with hearts for antennas beside an image of her "worst boyfriend" (Barry 15), and careful repetition of key words or images provide readers with clues about the story's underlying, but subtle revelation of self.

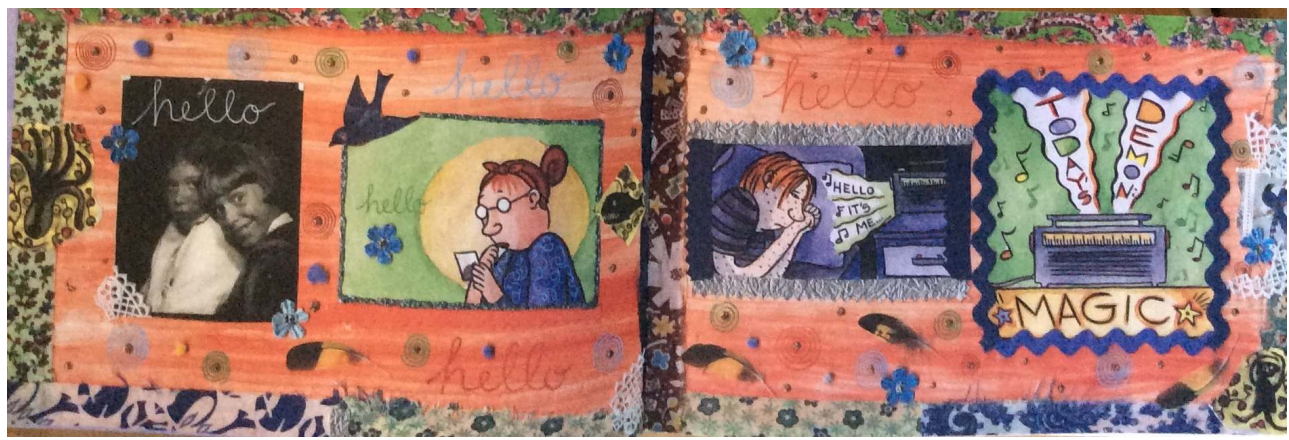

Fig. 1: Lynda Barry, One Hundred Demons (2002)

Copyright Lynda Barry, used with permission from Drawn \& Quarterly

The introductory pages thus entice interest, but they also provide associations between Lynda's personal experience and her understanding of the memory of that experience as well as its reworking in the context of her current life. These associations come to full light only after reading the story; as with all scrapbook pages, "the viewer must seek the hidden rhyme that connects the elements on the page" (Tucker, Ott, and Buckler 17). Packed with visual and verbal cues and pairings that gain in meaning within the context of the story, these two-page introductory collages are meant to be poured over again and again. Far from being a random or compulsive assembly of shapes, materials collected 
and found, colours, words, and visual media, their palimpsestic patterns are a textured portrayal of the everyday trauma reflected in the story that follows, and that the subject tries to come to terms with throughout the book.

The everyday materials used in one collage are reused in and reworked into other collage pages to suggest that the everyday trauma of her childhood and adolescent years can be contributed to a history, a series of experiences that span across time. Repeated features of her collage pages include spirals, wiggle eyes, gold and silver foil, feathers, flowers, pieces of lace, transparent tape, and, of course, a demon or two. Besides basic materials and shapes, images of self are also repeated. Among the most oft-repeated are a blackand-white cartoon image of a young sad-faced Lynda leaning against a clapboard covered building beside a sign that reads "Drink Moo Maid Milk" (Barry 26, 63, 183) (Fig. 2) and a personal photograph of Lynda roughly the same age that has been "defaced" or altered through scrapbooking (Barry 50, 110, 206, 217) (Fig. 3). The first image is linked to stories that have to do with remembering and forgetting, and the overarching question, "Who knows which moments make us who we are? All of them? The ones we never really thought of as anything special?" (Barry 36). The second accompanies stories that betray Lynda's sensitivity to experiences that altered her existing sense of self, such as the realization of her racial difference or, more painfully, that she was not 'advanced' enough for writing and literature" (Barry 215) or that she had been robbed of love (and acceptance) because of class, race, or not being cool enough (Barry 120). Repetition in these and other instances has a binding effect, weaving a specific sort of traumaeveryday trauma-through the stories.

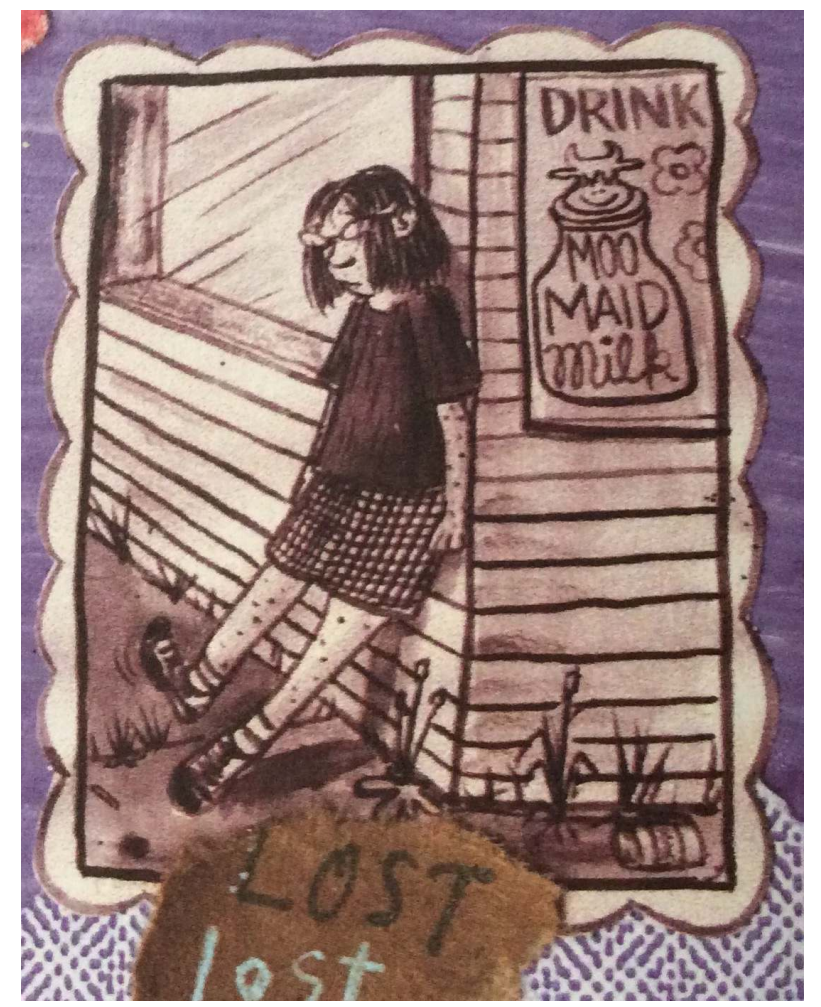

Fig. 2: Lynda Barry, One Hundred Demons (2002)

Copyright Lynda Barry, used with permission from Drawn \& Quarterly 


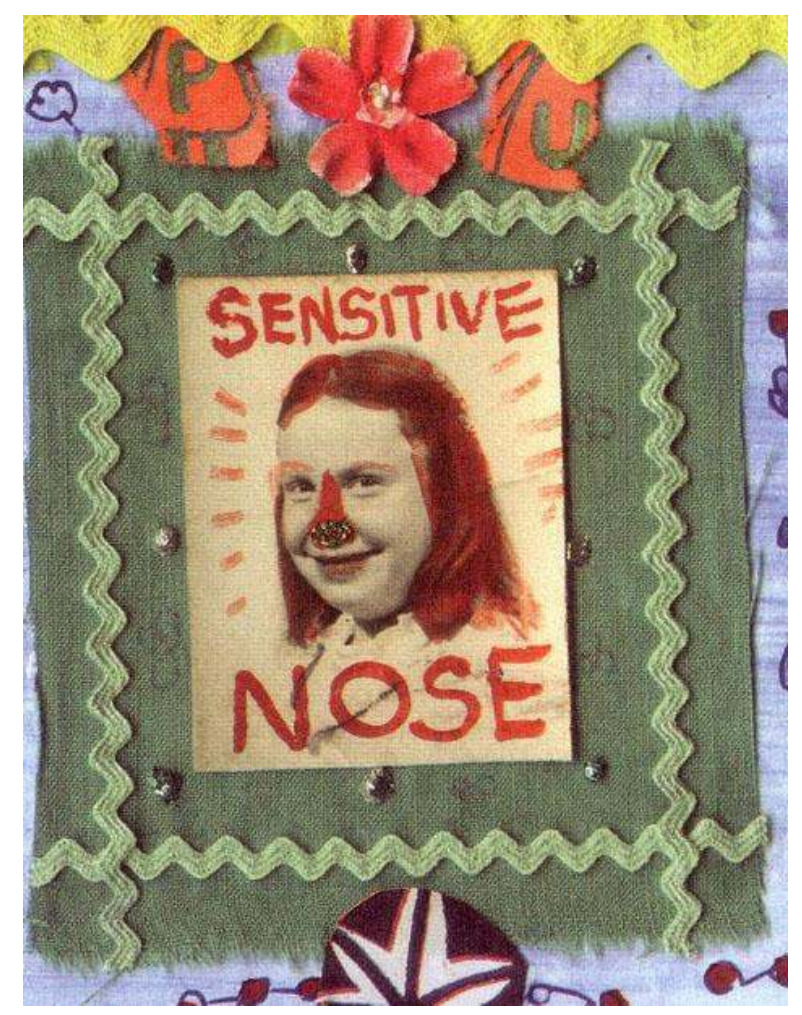

Fig. 3: Lynda Barry, One Hundred Demons (2002)

Copyright Lynda Barry, used with permission from Drawn \& Quarterly

However, throughout One Hundred Demons repetition also serves as a re-examination and reworking of an experience which has already been remembered and portrayed, visually and verbally, but that has not been fully or satisfactorily understood. Repetition is a highly self-reflexive narrative technique that complicates the original representation with variation, adjustment, expansion, in short, with interpretation. It not only points towards a need to add layers of meaning to the initial representation, but also to a dissatisfaction with or an incompleteness of that which is on the page. In One Hundred Demons, repetition marks the closing of each story as well; each story ends with a blank two-page water-coloured spread on which a feature of the introductory page is modified with an elaborate jagged-edged frame on which beads, glitter glue dots, fabric or ribbon overlays, cloth flowers, or other common scrapbooking materials are overlaid. Roughly the same size and positioned in the bottom right-hand corner of the second page, the repeated details on the story's closing page are visual metaphors, concentrated communications that sum up, even if only allusively, the story's main point.

Nonetheless, these altered images also seem incomplete, as if able to accommodate another round of modifications. Repetition, with slight alterations, of several of the cartoon drawings as well as personal photographic portraits, suggests how the original image is full of uncertainty or lapses of knowledge. It engages in the type of "revealing and concealing the self" Susan E. Kirtley attributes to comic form in general (Kirtley 149). Existing alongside previous and subsequent iterations, these repeated scrapbooked images create a complex layering of what was seen, what needs to be seen, and what can never be seen. The repetition of the same representation of self challenges the idea of a unified self by staging the need to continue adding new details and new interpretations, however tentative, to existing renditions of self. Within Barry's graphic memoir, this sort 
of repetition speaks to a self that seeks understanding and that is painfully aware of the divide between what is real and what is not, what is seen and what is felt, the outside and the inside of self. ${ }^{4}$

21 As reworked images of those already used in the context of other stories, repeated images also expose mediation-the framing and organizing of existing material-as inevitable, indeed necessary for self-representation. The necessity of mediation is highlighted in a much critically discussed two-panel page that opens the book portraying the authorprotagonist sitting at her desk drawing the very page we are reading. As she does so, she contemplates the process of self-portrayal asking whether her work is "autobiography if parts of it are not true [or if it is] fiction if parts of it are?" (Barry 7). One Hundred Demons' repeated nod towards mediation is paralleled visually in the scrapbooked treatment of the personal photographic portraits reproduced on the "surrealist collage" (Chute 292) cover pages of five of the seventeen short stories: "Common Scents" (Barry 50-51), "Resilience" (Barry 62-63), "Magic" (Barry 98-99), "The Visitor" (Barry 110-121), and “Lost and Found" (Barry 206-207).

In all five instances, personal photographic portraits of self have been adjusted through the author's hand with layers of scrapbooking materials. Each photograph has been tampered with; either words or other framing marks are scrawled over and around the personal photographic portrait, patterned paper or fabric is pasted overtop it, dainty flowers or pieces of lace adorn its borders, or particular facial features are accentuated with colour touch-ups (Barry 50). Overtly, even roughly mediated, these new, altered representations of self signal the need to adjust the images or, put differently, they signal an original lack in the personal photographic portrait. Scrapbooked personal photographs within a graphic memoir that explores the impact on self of everyday trauma strongly suggest that the identity recorded and inscribed in personal photographs proves insufficient to capture the subject's inner self.

23 At the hands of her scrapbooking techniques, Barry's personal photographic portraits relinquish their privileged value as evidential visual traces of that which existed in a particular time and place. ${ }^{5}$ Scrapbooking photographs provides access to trauma by breaking through the screen of representation informing personal photographs. Stripped of their documentary value, the personal photographs in Barry's cartoon universe are images like all others, representations born of and subject to the meaningful intervention of an artist's hand. The scrapbooked details-additions and subtractions, written words and colourful material frames-that adjust the personal photographs thus come to suggest that the original image, the one that supposedly captured the real, does not suffice to record her self. Left untouched, uncommented, unaltered, the personal photographs could not capture her fractured self, her "ability to exist in pieces [that] some adults call resilience" (Barry 70). They thus need to be changed.

The stories, too, are about Barry's struggles to adjust the traumatic happenings in her life and build a sense of self, regardless of how flawed. "Lost and Found" tells of Barry's lack of an extensive literary knowledge or formal writing possibilities. She tells us that in high school she wasn't "advanced enough for writing and literature" (Barry 215) and that "her trouble [with literary struggles and respect] ended when she started making comic strips" (Barry 215). In "Resilience" she considers how in school she "didn't fit in" with others (Barry 69) and comes to the understanding that her desperation to be "cool" and ok was fuelled by the fact that her inner life was a place she wanted to stay out of and that this thwarted identity (Barry 70). She concludes that she could construct an identity 
only when she "discovered how to give herself a feeling of wholeness" that, as she puts it, "was the closest [she] could come to ... to .... [she doesn't] remember" what (Barry 72).

The stories in One Hundred Demons are about building, finding, constructing an identity or a sense of self, despite growing up "in a violent house" (Barry 175), despite her emotionally destructive relationships with boys, and despite her rape as an adolescent. In them, Lynda writes the struggle to understand the effect of everyday trauma, of the "bad things [that] had gone on, things too awful to remember but impossible to forget" (Barry 65), on her own self. Setting out to create a sense of self that mends or, at the very least, begins to lessen the gap between who she is, what she is shown to be, and how she feels herself to be, the stories are ultimately about a child's and adolescent's inability to bridge the divide separating her inner self and her outer self, a hiding and showing, a not knowing and knowing that articulates the split self.

Like the stories they accompany, the scrapbooked personal photographic portraits serve to unveil the manœuvers-the storytelling, the framing, the creative processing-she went through to begin to build a sense of self, albeit a shaky, uncertain one. Scrapbooked personal photographs are truncated narratives, narratives comprised of incomplete fragments, which afford creators and readers alike the opportunity to visit and revisit experiences, emotions, and knowledges of self. Although "scrapbooks can be a method of resolving the conflicting claims between the real and the imaginary or remembered" (Tucker, Ott, and Buckler 3), in Barry's case it is a form that leaves the introductory reflection on the distinction between real and imaginary unresolved and the fraught interplay between inner and outer self open.

\section{Fragments towards a conclusion}

In his study of photography in modern American autobiography, Timothy Dow Adams briefly notes that photography and autobiography are narratives "characterized by a desire both to reveal and conceal, an attempt at reconciling a life with a self" (Adams xxi). I have argued that identities which have suffered from everyday trauma have turned to life-writing and personal photography to instate personal identities and representations of self that stand apart from normative definitions of self and restrictive models of self-representation. Lynda Barry has not only exposed personal photography and autobiography as necessarily regulating and obfuscating identity. Through various scrapbooking techniques, she has used personal photography to resist, critique, and work towards re-defining popularly accepted terms of self-representation and identity.

It has been noted that people often turn to personal photographs and the albums that collect them to "test their own identities against those on offer, a testing that takes place with greater urgency during periods of unrest" (Lee and Pultz 59). This is particularly true for subjects of trauma who, feeling a split between inner and outer self, are careful readers of their own photographs, using them as part of the process to present histories of self that run counter to the dominant views of what can be shown. Susan Sontag writes that "in the normal rhetoric of the photographic portrait, facing the camera signifies solemnity, frankness, and disclosure of the subject's essence" (Sontag 37-38). One Hundred Demons breaks from this normal rhetoric. In it, Lynda repeatedly addresses her inability to see self, to understand self through personal photographs. Barry's scrapbooked photographs disclose a self that exists through external representations of self, but that does not coincide with the self that cannot be seen, the one that exists on the inside. 

so central in graphic memoir, to reach far into questions of one's personal understandings and imaginings of self. Scrapbooking offers fertile ground to explore how those understandings of self are present alongside and against existing representations of self, such as the personal photographs most of us cherish as recordings of our past self. The fragmented quality of the scrapbooked photograph critically engages with the personal photograph as a traditional, authoritative form of self-representation. One Hundred Demons shows that scrapbooked personal photographs, with their hand-made quality that overtly betrays their fictiveness, reflect the "authentic" self more integrally than a personal photograph or a highly realistic portrait ever could.

a critical eye on the evidential status of photographic evidence, scrapbooking personal photographs also carries forth considerations of why such an intervention is necessary. In graphic memoirs that critically posit personal identity, and how it is represented to self and to others, as inevitably comprised of what can be seen and what cannot, the deliberate defacing of personal photographs through scrapbooking marks the personal photograph as the product of a process of self-imitation, as a kind of performance or "transformation of one's identity into an image" (Leet 114) that fits nicely into accepted models of self. Indeed, creative mediation is so forcefully pushed to the foreground through scrapbooking that the authority of personal photographs gives way to the affirming properties of creative intervention. Even when working alongside unaltered photographic images, scrapbooking is positioned to tie the representation of self, with all the fictionalizing that it entails, with the certainty of the memoirist's authorial subject position.

31 In One Hundred Demons, the scrapbook scribbles, modifications, and additions alert readers to the cartoon artist's creative dialogue with personal photographic images and with the aesthetics of self-representation. Scrapbooked personal photographs announce the artist's crafted, fictional response to the personal photographs that, like most photographic portraits, have most probably been taken "to record our own lives" (J. Hirsch 123) and saved to archive a family history, a collective autobiography (see Garat) of which each memoirist is a part. For Barry, eschewing traditional realism and challenging secure knowledge through scrapbooking is a means to bring to light moments of knowing self, or of knowing that self cannot be fully known because not fully representable. The scrapbooking of personal photographs in her graphic memoir actually adds to the types of gaps, condensations and substitutions that express the split of self theorized by many critics of autobiography and trauma alike (see Stacey 98). In it, scrapbooked personal photographic portraits address and trouble the relationship between outer and inner expressions of self, a split that is "felt most strongly by people affected by trauma" (El Rafaie 63).

The scrapbooking of personal photographs in a predominantly cartoon visual narrative universe not only comments on the way in which personal identity is established through visual representation; it also comments on how representation restricts and, at the same time, expands upon what is seen and known of self. The manipulation of personal photographs through scrapbooking techniques in the graphic memoir universe informs how the represented self-especially the visually represented self-is understood, created, and made meaningful by itself and through the representations of self it depends on for that understanding. That the photographic image is mechanically made and thus tightly associated to the real makes it a particularly powerful visual representation for 
those who, like Barry, present realities that do not coincide with the way reality felt to them. Scrapbooking allows them to infringe on the authority of the personal photographic image by adjusting it and adding poignant layers of meaning to it. Scrapbooking is a personal and malleable form of representation often used, especially by female graphic memoirists, to communicate alternative histories to those recorded in personal photographs.

Susanna Egan has argued that "instability in perspective, narration, medium, or authority becomes not merely appropriate for expression because it feels stable or real. The genres that eschew traditional realism and challenge secure knowledge become the means for moments of reality and knowing" (Egan 28). In her explorations of self through personal photography, Barry has adopted scrapbooking techniques and forms that better speak to a divided, multiple, perhaps unknowable and unrepresentable, but unique self. Scrapbooking, which "shuffles and recombines the coordinates of time, space, location, voice, and memory" (Tucker, Ott, and Buckler 16), challenges established knowledges of self through its very form. It is a form of life-writing that reflects and thus exposes the fractured self through its fractured narrative.

Scrapbooking personal photographs (and other representations of self) is a narrative technique that allows cartoonists such as Barry to represent their physical identities "in ways that reflect their own innermost sense of self" by adding "further layers of meaning to their self-portraits (El Rafaie 51). In this and other graphic memoirs that relate everyday trauma, scrapbooked personal photographs function to reveal subjectivity in its full processural dynamics; they accentuate its instability, its unknowingness, its temporality, its fictiveness. Scrapbooked photographs evoke layered selves, selves who constantly struggle to understand self through acts of visual representation. Scrapbooking thus offers Barry and other graphic memoirists (Anne Marie Fleming, Gusti, Aline Kominsky-Crumb) not a means to excavate a self through memory and its forms of representation, but rather to build up, compile layers of images of self to reach a more authentic, because less coherent and definite understanding of self.

\section{BIBLIOGRAPHY}

Barry, Lynda. One Hundred Demons. Seattle: Sasquatch Books, 2002.

Boman, Charlotte. "Peculiarly marked with the character of our own time: Photography and Family Values in Victorian Domestic Journalism". Victorian Periodical Review 47.4 (Winter 2014): 538-550.

Bourdieu, Pierre. Photography: A Middle-brow Art (1965). Trans. Shaun Whiteside. Stanford: Stanford UP, 1990.

Brick. Depresso or, How I Learned to Stop Worrying and Embrace Being Bonkers. London: Knockabout Books, 2010.

Buss, Helen. Mapping Our Selves: Canadian Women's Autobiography in English. Montreal: McGillQueen's UP, 1993. 
Chute, Hillary. Graphic Women: Life Narrative and Contemporary Comics. New York: Columbia UP, 2010.

Clarke, Graham. The Photograph. Oxford: Oxford UP, 1997.

Cunningham, Darryl. Psychiatric Tales: Eleven Graphic Stories about Mental Illness. New York: Bloomsbury, 2011.

Eakin, Paul John. How Our Lives Become Stories: Making Selves. New York: Cornell UP, 1999.

Edwards, Steve. Photography: A Very Short Introduction. Oxford: Oxford UP, 2006.

Egan, Susanna. Mirror Talk: Genres of Crisis in Contemporary Autobiography. Chapel Hill: U of North Carolina P, 1999.

El Rafaie, Elisabeth. Autobiographical Comics: Life Writing in Pictures. Jackson: U of Mississippi P, 2012.

Feis, Brian. Mom's Cancer. New York: Abrams Publishing, 2006.

Fleming, Anne Marie. The Magical Life of Long Tack Sam: An Illustrated Memoir. New York: Riverhead, 2014.

Garat, Anne-Marie. Photos de familles. Paris : Éditions du Seuil, 1994.

Gilmore, Leigh. "Limit Cases: Trauma, Self-Representation, and the Jurisdictions of Identity". Biography: An Interdisciplinary Quarterly 24.1 (2001): 128-139.

Groensteen, Thierry. Comics and Narration. Trans. Ann Miller. Jackson: UP of Mississippi, 2013. Guibert, Emmanuel. Alan's War: The Memories of G. I. Alan Cope. New York: FirstSecond Books, 2008. Gusti. Mallko y Papá. México D.F.: Océano Travésa, 2014.

Helfand, Jessica. Scrapbooks: An American History. New Haven: Yale UP, 2008.

Herman, Judith Lewis. Trauma and Recovery: The Aftermath of Violence. From Domestic Abuse to Political Terror. New York: Basic Books, 1997.

Hirsch, Julia. Family Photographs: Content, Meaning and Effect. New York: Oxford UP, 1981.

Hirsch, Marianne. Family Frames: Photography, Narrative and Postmemory. Cambridge, MA: Harvard UP, 1997.

Holland, Patricia. “'Sweet it is to scan ...': Personal photographs and popular photography". Photography: A Critical Introduction. Liz Wells (ed.). London: Routledge, 2001, 115-158.

Holland, Patricia. "Introduction: History, Memory and the Family Album”. Family Snaps: The Meanings of Domestic Photography. Jo Spence and Patricia Holland (eds.). London: Virago Press, 1991, 1-14.

Hutcheon, Linda. The Poetics of Postmodernism. London: Routledge, 1989.

Kacandes, Irene. "Experimental Life Writing". The Routledge Companion to Experimental Literature. Joe Bray, Alison Gibbons, and Brian McHale (eds.). London: Routledge, 2012, 380-392.

Kirtley, Susan E. Lynda Barry: Girlhood through the Looking Glass. Jackson: UP of Mississippi, 2012.

Kominsky-Crumb, Aline. “The Aline Kominsky-Crumb Interview”. The Comics Journal 139 (Dec. 1990): http://www.tcj.com/the-aline-kominsky-crumb-interview/ (last accessed 19 June 2018)

Kominsky-Crumb, Aline. Need More Love. London: M Q Publication, 2007. 
Kuhn, Annette. "Remembrance". Family Snaps: The Meanings of Domestic Photography. Jo Spence and Patricia Holland (eds.). London: Virago Press, 1991, 17-25.

Lee, Anthony W. and John Pulz. Diane Arbus: Family Albums. New Haven: Yale UP, 2003.

Leet, Sri-Kartini. "Negotiating Identities: The Portrait as Representation”. Reading Photography: A Sourcebook of Critical Texts 1921-2000. Sri-Kartini Leet (ed.). Farnham: Lund Humphries, 2011.

Marcetto, Marisa Acocella. Cancer Vixen: A True Story. New York: Pantheon Books, 2009.

Ôtié, Philippe, and Li Kunwu. A Chinese Life. New York: Abrams Publsihing, 2012.

Pedri, Nancy. "The Forbidden Narratives of Looking: Photography and the Anxiety of SelfRepresentation". Rewriting Texts, Remaking Images: Interdisciplinary Perspectives. Leslie Boldt-Irons, Corrado Federici, and Ernesto Virgulti (eds.). New York: Peter Lang, 2010, 261-268.

Reynolds, Dawn Marie. Beyond Scraps: Narrating Traumatic Health Experiences through Scrapbooking. Proquest, Umi Dissertation Publishing, 2011.

Rose, Gillian. Doing Family Photography: The Domestic, the Public, and the Politics of Sentiment. Farnham: Ashgate, 2012.

Rugg, Linda Haverty. Picturing Our Selves: Photography and Autobiography. Chicago: The U of Chicago P, 1997.

Scholinski, Daphne, and Jane Meredith Adams. The Last Time I Wore a Dress. New York: Riverhead Books, 1997.

Sontag, Susan. On Photography. New York: Farrar, Strauss and Giroux, 1977.

Spiegelman, Art. Maus I: A Survivor's Tale: My Father Bleeds History. New York: Pantheon Books, 1986.

Spiegelman, Art. Maus II: A Survivor's Tale: And Here My Troubles Began. New York: Pantheon Books, 1991.

Stacey, Jackie. Teratologies: A Cultural Study of Cancer. London/New York: Routledge, 1997.

Tagg, John. The Disciplinary Frame: Photographic Truths and the Capture of Meaning. Minneapolis: U of Minnesota P, 2009.

Tamas, Sophie. "Scared Kitless: Scrapbooking Spaces of Trauma". Emotion, Space and Society 10 (2014): 87-94.

Tucker, Susan, Katherine Ott, and Patricia Buckler. The Scrapbook in American Life. Philadelphia: Temple UP, 2006.

Tucker, Susan, Katherine Ott, and Patricia P. Buckler (eds.). "An Introduction to the History of Scrapbooks". The Scrapbook in American Life. Susan Tucker, Katherine Ott, and Patricia P. Buckler (eds.). Philadelphia: Temple UP, 2006, 1-23.

Williamson, Janet. Crybaby! Edmonton: NeWest Publishers, 1998.

\section{NOTES}

1. See Rose (25-40), who argues that the indexicality of family snapshots fuels this type of documentary engagement with them. See Edwards, who describes family photo albums as classical sites of "storytelling as memory" (122). 
2. See Williams for how graphic memoir has been used as therapy for patients who suffered trauma; see Tamas (89-90) on the therapeutic benefits of scrapbooking.

3. Scrapbooking began to center on photography as photographic methods continued to evolve (Reynolds 14-15); see also Tucker, Ott, and Buckler 11-12.

4. Several critics have commented on the repetition of the visual portrayal of self in graphic memoir, highlighting how this repeated embodiment presents a self that "oscillates between various fashionings of the subject" (Groensteen 108).

5. See Kirtley who, in her book chapter "Scrapbooking the Self: 'Autobifictionalography' in One Hundred Demons", argues that "Barry [...] assembles snapshots of herself through her comic art along with other materials, artistically presenting a vision of selfhood that incorporates artistic renditions of identity along with photographic evidence and mass-produced artifacts, blending an inner vision of character with historical documentation" (Kirtley 153).

\section{ABSTRACTS}

A close reading of scrapbooked personal photographs in Lynda Barry's One Hundred Demons, a graphic memoir that relates the impact of everyday trauma on self, shows how this narrative technique resists, critiques, and works towards re-defining popularly accepted terms of selfrepresentation and identity. By adding layers of meaning to existing portrayals of self, scrapbooking personal photographs not only addresses but troubles the split between outer and inner expressions of self so powerfully felt by those who suffer everyday trauma. It also accentuates the instability, unknowingness, and incompleteness of a traumatized identity, thus presenting a more authentic, because less coherent and definite understanding of self.

Une lecture attentive des photographies d'elle-même que Lynda Barry a réunies dans l'album Mes cent démons, BD autobiographique qui relate l'impact des traumatismes du quotidien sur le sujet, révèle à quel point cette technique narrative s'oppose à ce qui est communément admis en matière de représentation de soi et d'identité, en fait la critique et en esquisse une nouvelle définition. En ajoutant des niveaux de sens supplémentaires à des portraits de soi existants, l'activité consistant à recueillir en un album des photographies de soi non seulement interroge mais aussi complique la schize entre les tensions conscientes et inconscientes qui anime le sujet souffrant de traumatismes du quotidien. Elle accentue également l'instabilité, la méconnaissance et l'incomplétude du sujet traumatisé, en en présentant ainsi une compréhension plus authentique car moins structurée et moins définie.

\section{INDEX}

oeuvrecitee One Hundred Demons, Mes cent démons

Keywords: identity, graphic memoir, photograph, album, scrapbooking, self, trauma

Mots-clés: identité, BD autobiographique, photographie, album, scrapbook, sujet, trauma 


\section{AUTHORS}

\section{NANCY PEDRI}

Nancy Pedri is Professor of English at Memorial University of Newfoundland, Canada. Her major fields of research include word and image studies, photography in literature, and comics studies. She has edited several volumes, including one on photography in comics for Image \& Narrative and another on mixed visual media in comics for ImageText. She has published many articles in her fields of interest, and her co-authored book, Focalization in Action, which examines the focalization concept in a broad range of comics is under review with Ohio State University Press. Her co-authored article, "Focalization in Graphic Narrative," won the 2012 Award for the best essay in Narrative. 